\title{
Holidays under the hegemony of hyper-connectivity: getting away, but unable to escape?
}

\author{
Richard Voase \\ Final version post-peer review, accepted for publication $1^{\text {st }}$ May 2018. \\ Publication: Leisure Studies, 37 (4) 384-395. \\ https://doi.org/10.1080/02614367.2018.1475503
}

\begin{abstract}
Holidays have been imagined as occasions of escape and liminal leisure. This conceptualisation requires re-evaluation as a consequence of the widespread adoption of portable communication devices (smartphones) and the use of Web 2.0 interactive platforms (social media). Studies suggest that the gratifications of contact with the 'other', and the enjoyment of the license associated with the liminal condition, are compromised by endemic contact with the domicile. An analysis draws on the work of Heidegger and Althusser, and is supported by insights from Foucault, Arendt and Lacan. It is argued that users are 'enframed' and subjected by their devices. This re-imagining is representative of an evolving change in the human condition, of which the compromising of tourism-as-escape is but one manifestation.
\end{abstract}

Keywords: tourism; holiday; escape; liminal; smartphone; social media.

\section{Introduction}

Francis Fukuyama's The End of History and the Last Man appeared in 1992. It acquired international fame, propelled in part, no doubt, by the melodrama of its title.

Fukuyama's tome was a speculation on the likely state of the world in the twenty-first century. His argument was that, at his time of writing, consensus seemed to have gathered around the concept of liberal democracy. The twenty-first century would witness the 'end of history' in the sense that the conflict of ideas over forms of government seemed to have reached a final destination. The 'last man', a term he borrowed from Nietzsche, was the projected inhabitant of this post-ideological world, eschewing risk, and pursuing comfort and security.

However, the early years of the new century were to see human life transformed by two technological developments, the full implications of which were unanticipated. The first was the proliferation of hand-held communication devices with internet connection. The second was the arrival of so-called 'Web 2.0' and the creation of a cyber-interactive social world. The writer of a recent retrospective of Fukuyama's book asks whether digitally-induced passivity is leading to a cultural apocalypse: to witness all the human occupants of a railway carriage staring at an illuminated device can be considered a vision of dystopia (Glaser, 2014). The 'last man' had, perhaps, taken the stage.

The purpose of this paper is to discuss whether the smartphone and its potentialities are leading to the 'end of the holiday' as known. The holiday has been conceptualised as a 
form of escape. The discourse of tourism-as-escape will be examined, as will meanings commonly ascribed to the terms 'leisure' and 'liminal'. The importance of encounters with the unexpected will be surveyed. It will be argued that portable devices and social media are compromising the license normally imputed to vacational experience. A conceptual analysis draws on the work of Heidegger, and is supported with ideas from Althusser, Foucault, Lacan and Arendt. The conclusion is not so much the end of the holiday per se, but a cyberneticisation of human life, holidays tout compris. It is important to note that this study, though it seeks to address what will be termed the 'human condition' (Arendt, 1958), is culturally-situated in a Western perspective.

\section{Tourism-as-escape: so twentieth century?}

Fin-de-siècle writings from the twentieth century are apt to refer to 'escape' as a prime reason and benefit for taking a holiday. Ryan, to illustrate this point, makes reference to Willy Russell's stage play, and subsequent cinematic film, Shirley Valentine. The protagonist is a British housewife who, bored with a husband obsessed with routine, takes herself to Greece on a solo holiday. She finds cathartic release through a romantic encounter with a fisherman. Ryan offers examples, known to him, of life imitating art. He observes that such periods of escape, involving active separation from home and family, appear to provide opportunity for self-examination and life-changing action (1997, pp. 1-3).

For Krippendorf, escape is the prime reason for a holiday. He juxtaposes the otherness of the tourist trip against the demands of working life; ancillary benefits include opportunities for self-determination (1987, pp. 25-27). Existential aspiration is seen also by Hamilton-Smith as central to tourism-as-escape. He cautions that such ambition does not have to be linked with adventurous intentions: a holiday may appear mundane, but levels of satisfaction may be high (1987, pp. 333-9). Cohen and Taylor, in their broad survey of modes of resistance to the normative demands of life, see holidays as one component of a portfolio of ways for subverting the everyday, and a route to selfdetermination (1992, pp. 132).

The 'end of tourism' has antecedence. Lash and Urry argued that mass tourism should be seen as a cultural consequence of organised capitalism. Human subjects worked for mass employers in fixed geographical locations, from which it was necessary to resort, literally, to another fixed place for recuperation. As employment became more fragmented, and electronic communications liberated the linking of work to specific spaces, the need to 'escape' receded. In this way, disorganised capitalism presaged 'the end of tourism' (1994, pp. 259-60). Urry also made a pivotal contribution to the evolving sociology of tourism. His initial paradigm for tourism was as a 'binary division between the ordinary/everyday and the extraordinary' (1990, p. 11); but his later works address a broader concept of the mobility of people, employment, residence and information $(2000,2007)$.

\section{The smartphone: harbinger of hyper-connectivity}

At the time of writing, in the United Kingdom as an example, some $85 \%$ of the adult population own smartphones: that is to say, mobile communication devices that offer 
internet access (Deloitte, 2017, p.12). The devices offer telephone, text and e-mail facilities, and can be equipped with pieces of downloadable software, known as applications. These 'apps' execute particular tasks. For example, in the field of travel, apps are available to deliver weather reports, railway timetables, destination guides, and satellite navigation. Thus, these devices offer a facility to the user to navigate their realworld lives and environs, in addition to offering access to a world of social communication to rival the real.

The term 'Web 2.0' first seems to have appeared circa 2005 (Fuchs, 2014, p. 32). It is best understood as a platform for interactive media, of which Facebook, Twitter, and latterly SnapChat and Instagram, are presently dominant. Previous internet platforms had offered functionally-specific opportunities for social interaction, for example, reuniting friends. However, Web 2.0 provides a platform for making, sharing, developing and discarding social acquaintance on a much broader basis. Parallel developments in ecommerce and geographical information systems have made possible the management of money, trading, navigation, and shopping, using mobile devices.

The usage of social media has become globally ubiquitous. Facebook started as a sharing site for college students in the United States, opening to all users in 2006. It now claims over two billion active users (Statista, 2017). Twitter is a micro-blogging site that also started in 2006, now claiming over three hundred million active users (Statista, 2017a). These two have acquired institutional status. All sorts of organisations, private, commercial, and governmental, have accounts. Instagram and SnapChat are currently on an upward trajectory as 'edgier' offers. Instagram is primarily oriented toward photographic content. A defining feature of SnapChat is that transmitted content is self-deleting after a time interval.

Thus, Web 2.0, combined with the ubiquity of the smartphone, has made possible a virtual social world to rival the real. The difference with the real world, inter alia, is the absence of geographical boundary. Location becomes irrelevant.

\section{Home and away: the holidaymaker quandary}

\footnotetext{
The human condition comprehends more than the conditions under which life has been given to man (sic). Men are conditioned beings because everything they come into contact with turns immediately into a condition of their existence...the things that owe their existence exclusively to men...constantly condition their human makers... That is why men, no matter what they do, are always conditioned beings (Arendt, 1958, p.9).
}

Thus speaks the social theorist Hannah Arendt in The Human Condition (1958). Her overall point is that as humankind augments its potentialities through technological and social scientific advances, it cedes control over the human condition to those very advances. This is arguably a message of greater relevance now than in 1958 when the words were written. This author's purpose, as stated earlier, is to focus on the concept of the holiday, and ask whether, and how, through developments in technology, the holidaymaker is evolving from an escapee, gifted with powers of existential selfdetermination, into a being conditioned by technologies from which there is no escape. 
Cyberoptimistically, the smartphone can be regarded as an experiential asset in managing and navigating the tourist trip. Wang, Park and Fesenmaier affirm that smartphones are engineering a generic change in the human condition: '...the increasing penetration of mobile devices in people's daily life will have a profound influence on how people think and behave'. However, they show how smartphones equipped with applications (apps) can be of apparent benefit. Analysing publicly-available positive reviews of travel apps, they conclude that the apps enable tourists to be 'more creative and spontaneous'; and that the apps also facilitate interaction amongst tourists of no prior acquaintance (2012, pp. 385-6). A note of caution needs to be sounded, inasmuch as they exclude negative reviews of apps, because such reviews focused on usability problems (2012, pp. 373). One could ask, if the technology is unreliable or difficult to use, is that not a feature of the user experience?

However, for the purpose of this paper, the more salient facet of the smartphone's potential is the facility to keep in touch with family, friends and workplace via social media. A study by White and White suggested that to experience home whilst away is an ambiguous benefit. A desire to maintain social interaction with home was mixed with a desire for a break from the same. The idea of the holiday as a transition into a world unconstrained by the strictures of domestic accountabilities had been compromised. 'Tourism-as-escape' was now a concept that, they suggest understatedly, 'might be usefully re-interpreted'. They also suggest that the holiday had been emptied of its 'liminal' qualities (2007, p.101). This is a point pivotal to the argument of this paper, to be addressed shortly.

Ambivalence on the part of device users is also revealed through the work of Silas, Løvlie and Ling (2016). Qualitative research amongst backpackers revealed a tension between the use of the device, and the desire to achieve detachment from both it and the familiarity of the domicile. Devices sequestered more time than intended, because their usage was not always either speedy or straightforward. There was resonance with the findings of White and White, in that families at home had expectation that their progeny would keep in touch and enable them to perform 'remote parenting' (2016, p.48). Despite apparent desire to separate from usage of the devices, all subjects confirmed they used them on a daily basis. Aspired detachment was compromised by compulsion to use.

There is a further corpus of research relating to the nature of smartphone use by travellers: for example, see Dickinson et al (2014); Kirillova \& Wang (2016); Park, Kim, Shon \& Shim (2013); Wang, Xiang \& Fesenmaier (2014). Equally, there are studies of the relationship between technology use, technology dependence and the everyday: for example, see MacKay \& Vogt (2012); Wang, Xiang \& Fesenmaier (2016). The present paper, however, seeks to take the topic into a different direction by examining the existential and experiential questions outlined earlier. Has the concept of 'tourism-as-escape' been compromised? What is it about the tourist experience, as known, that may thrive less well in a context of constant contact with the domicile? Further, to what extent is it appropriate to speak of the adoption of these technologies as a change in the 'human condition'?

The exploration begins with a consideration of the matter of aspired detachment while away, as uncovered by Silas et al (2016) above; see also Wang \& Alasuutari (2017). The suggestion is that the nature of tourist experience, as normatively constructed, is 
modified by the technological potential for constant contact with the domicile. The issues to be addressed are, first, what is known about the innate nature of the tourist experience that makes it memorable; and second, to what extent do gratifications depend on being truly 'away'? One facet of such rewards, as reflected in literature and research, is the encounter with the unexpected (Hyde and Lawson, 2003). In order to underline the importance of this point, a survey of examples is offered.

\section{Gratifications: the salience of the serendipitous}

Literary evidence of the value of encounters with the unexpected is apparent in the novel, Memoirs of a Tourist, by Stendhal (1962, orig. 1838). Stendhal's 'tourist' finds satisfaction, not so much in well-known sights, but in small encounters. For example, on one occasion, Stendhal's traveller is strolling in the small town of Beaucaire. Attracted by a profound odour, he sets out to investigate, discovering a street full of walls of onions and garlic, the stench of which causes him to flee (Stendhal, 1962, pp. 184-5). The 'tourist' may have fled, but, paradoxically, he becomes, through this encounter, a satisfied tourist. MacCannell's insightful observation is that Stendhal's 'tourist' is motivated by the need to have something new to say. Experiences that give rise to episodic memories and provide material for conversation are not so much the extraordinary, but the unexpected (2001, pp. 32-33).

Another literary example is to be found in the oft-cited sonnet by the nineteenth-century English poet, William Wordsworth, I Wandered Lonely as a Cloud. Wordsworth sets out to walk, alone, in the English Lake District, with no particular end in mind except to deploy, perhaps, his artist's eye for the serendipitous (Grit, 2014, p.133). He encounters, unexpectedly, a host of daffodils beside a lake, 'ten thousand dancing in the breeze'. He records his experience in poetry, and speaks of how this unexpected encounter provided him with episodic gratification: 'I...little thought, what wealth the shew (sic) to me had brought' (Wordsworth, 1969, pp. 552). As with Stendhal's tourist, Wordsworth's serendipitous encounter with the daffodils had given him something to talk about: witness the fact that this author is able to relate the tale two hundred years later.

The gratifications of the unexpected also emerge through formal studies. Hyde and Lawson, for example, found that an evolving itinerary, the willingness to take risks, and, quote, 'a desire to experience the unexpected' were key benefits of the trip for independent travellers (2003, p. 13). A study undertaken by Huxley amongst backpackers revealed interest in small encounters because they constituted a contrast with the everyday, and afforded novel subject matter for conversation. One subject spoke of having viewed the 'must sees' such as the Eiffel Tower and the Taj Mahal, but placed greater value on having encountered

\footnotetext{
...tiny vignettes of relatively mundane life that end up being really fascinating because it's so normal for whatever part of the world, but so different from my daily existence. (Huxley, 2004, p. 39).
}

These examples suggest that the tourist seeks to 'get away from it all' in a qualitatively positive sense. Also, it is worth recalling Hamilton-Smith's observation that the satisfactions need not depend on adventurous holiday intentions (1987, pp. 333-9): a mass-market holiday in the company of British people, eating British food and speaking 
English, but in a country other than Britain, still delivers novelty in terms of new social acquaintance. Indeed, serendipitous encounters may occur between travelling companions. Dann reports a research subject citing a holiday benefit as 'getting to know for the first time the person to whom they had been married for some years' (1977, p. 190).

These examples arguably establish a case that the benefits and gratifications of tourism would seem to relate, less to encounters with the pre-scripted, than to encounters with the unforeseen. The issue that now needs to be addressed is, to what extent do such benefits depend on separation, as well as removal, from the home environment? Reference was made earlier to the concept of the 'liminal'. The following paragraphs seek to offer a critical appraisal of this concept, how it may be usefully applied to understanding tourist experience, and how the compromising of the liminal may be a consequence of the widespread adoption of the technologies and media platforms under study.

\section{'Leisure' and the loss of the liminal}

Krippendorf wrote that travel is 'the most liberating form of leisure' $(1987$, p.27). It is easy, facile perhaps, to concur with this idea. However, 'leisure', by definition, has boundaries. The French antecedent to the English word 'leisure' is loisir; and loisir is related to the word loi, meaning 'law'. The French word loisible means 'permissible' or 'optional' (Mansion, 1967). Thus, before a discussion of the liminal begins, it is important to bear in mind that 'leisure' is not necessarily a time of license. It is, rather, a time when alternative pursuits are permitted ${ }^{1}$.

Reference was made to the 'liminal' by White and White, when they suggested that the potential of mobile communications devices had compromised the concept of tourismas-escape (2007, pp. 101). The term was deployed in the concluding paragraphs of their article and was not developed. However, 'the liminal' has been commonly deployed to frame an understanding of the way tourist experience and behaviour contrasts with, and is on occasions oppositional to, the everyday: see for example Pielichaty (2015); Pritchard \& Morgan (2010); Ringer (1998); Shields (1990); Voase (2002, pp. 8-9). That said, the origins of the term 'liminal' are very specific, in contrast with the looseness with which the term is sometimes deployed. It is important for the argument of this paper that a clear meaning be understood. For that reason, the critical exposition below addresses the origins of the term.

The term 'liminal' is derived from the Latin, limen, meaning 'threshold'. It is also related to the English word, 'limit'. The Roman structure that stretches across northern England from Carlisle to Newcastle-on-Tyne, known as Hadrian's Wall, was known to the Romans as the limes. Implicit in the term 'limes' in the sense of 'frontier' is that it is a place on the edge: a place where different worlds collide, a zone where different

\footnotetext{
${ }^{1}$ The author is aware that the concept of leisure has seen some renegotiation under the influence of neoliberalism: a shift away from what one might term principled recreation, to a sense of individual entitlement to license. See for example Griffin et al (2009) and Griffin et al (2016).
} 
peoples interact and where accepted protocols and laws become, perhaps, rather fuzzy. It is thus apparent why 'the liminal' is an attractive concept for attempts to explain the experiential dimensions of tourist destinations and holiday behaviour. But a more detailed examination of its origins is required in order that its true meaning, and thus its analytical utility, can be evaluated.

Transitional life phases, such as adolescence, follow a similar pattern in many societies. Such was the observation of ethnographer Arnold van Gennep (1873-1957) who, in Rites de Passage (1960, orig.1909) posited three phases for the rite of passage known as adolescence: first, separation; second, removal; and third, aggregation. These phases, with illustrations by this author, manifest themselves as follows. First, 'separation': the adolescent struggles with the changes he/she is experiencing and withdraws from dialogue with parents. Second, 'removal': the subject seeks solace with like-minded adolescents and 'escapes' into music, stylised clothing, social media, or other distraction. Third, 'aggregation': the adolescent returns, empowered with a sense of adult individuality. The second phase, the 'removal' phase, was labelled, by van Gennep, the 'liminal' phase (1960).

Liminal phases are recognisable by 'the blend they offer of lowliness and sacredness, of homogeneity and comradeship'. This was the elaboration offered by anthropologist Victor Turner (1920-1983) who revived the concept in the 1960s (1969, p. 96). Our theoretical adolescents are revisited to illustrate Turner's point. They feel 'lowly', perhaps concealing themselves in hoods; 'sacred' status is ascribed to shared cultural expressions such as music; an 'homogenous' dress sense emerges, shared through 'comradeship' with other adolescents. Turner coined the term communitas to refer to the egalitarian nature of relationships during the liminal phase. He saw the hippy culture of his era, centred on music, clothing and lifestyles, as an example of liminal egalitarianism (1969, p. 112).

The application of the 'liminal' concept in tourism runs thus: human subjects on holiday enter a phase of 'separation' through 'removal' to temporary residence in another place where protocols may differ. Empowered by the challenge and opportunity of the 'other', they suspend the protocols whereby they live in their home location. They may drink more than they normally would, seek out sexual encounters with strangers, socialise with people with whom they may not normally socialise, visit the kind of places they may normally avoid, and consume food they would not encounter at home. Thus, a destination can be regarded by a visitor as a liminal zone. The holiday thereby becomes an episode that gives license to elements of liminal behaviour.

However, this author argues that the 'liminal' as theorised by van Gennep and Turner is less a label, than a useful tool for analysis. Close examination of specific vacational phenomena reveals that the term needs to be applied with care. For example, so-called 'voluntourism', whereby youth from the wealthy west visit a less privileged part of the world in order to, let us say, help look after orphans for a two-week period, seems at first sight to resemble liminal behaviour: a rite of passage, albeit purchasable and prepackaged. But arguably such a holiday does not fit easily with the character of the liminal, which as theorised by Turner, requires egalitarian relationships. The truth, albeit perhaps unwelcome, is that rich 'we' helping poor 'you' is counterfeit communitas. To develop this example further is beyond the intended parameters of this present paper; but the point is, that there is more to the liminal than the term itself. 
If, then, we consider the smartphone on holiday, and ask whether it alters the context of the liminal, it is apparent that it takes away van Gennep's 'separation' as the precondition to the 'removal' phase. Indeed, to become separated from the actual device has been shown to generate states of heightened anxiety in users (Hartanto and Yang, 2016). Possession of the technology generates a mutual expectation that 'away' will maintain contact with 'home', underpinned by users' fears of not being involved, or not included, in the affairs of the domicile (Wolniewicz, A. et al, 2017). Thus, for example, a backpacking trip may be an act of removal, but it ceases to be a rite of passage involving separation and now has strings attached: apron-strings, one could say (Silas et $a l, 2016$, p.48). The holiday experience cannot properly be described as 'liminal' if separation has not occurred. The young person, equipped with smartphone, is in that sense never away from home. He/she continues to be parented by those whose interest in their well-being is natural and continual. We now turn to the writings of Heidegger to illuminate the consequences for human subjectivity.

\section{You've been framed: Heidegger's social technology}

Philosophy can be understood as an intellectual pursuit of truth, an existential practice to inform a way of life, and, in more recent times, conceptual instrumentalism (Sandywell, 2011, pp. 468-9). It is with this latter purpose in mind that we invoke Heidegger's The Question Concerning Technology, first published in 1953. In one of his more lucid works, he deploys his habit, developed in his major work Sein und Zeit (Being and Time) of creating his own terminology in German, but complements the intricacies of his exposition with clear, even commonplace, illustrations. These include the technologies involved in the making of a silver chalice and a hydro-electric dam on the river Rhine (2011, pp. 220, 224). For the present purpose, it is necessary to hear how the principles he sets out may inform our understanding of the impact of the smartphone and Web 2.0 on the human condition.

First, Heidegger asserts that the 'essence' of technology is not technological. If human subjects believe that technologies are neutral, or if they allow themselves to revere them uncritically, understanding will be occluded. The essence of technology comprises the assemblage of concepts, human labour and human usage that surround them. Technologies are thus a social activity (2011, pp. 216-7).

Second, a technology, once available, constitutes an element in what Heidegger termed the Bestand. This has been translated into English as 'standing-reserve' (2011, p. 225).

Bestand is however a broad term in German. Heidegger's intended meaning is that once a technology exists, it is present and available; and its availability alters the condition of life of the human subjects associated with it. The meaning of Bestand might be better expressed in English by turning an adjective into a noun: 'the available'. In the Englishspeaking workplace, the term may be 'resources'. Humans are sentient beings, but in the contemporary workplace they are now, we are told, 'resources'; see also Braver (2009, p.86) and Miller (2012, p.274).Those 'human resources' may also constitute, quite literally, a 'standing-reserve', as the 1.4 million Britons on a zero-hours contract may attest (ONS, 2017). 
We must therefore ask how technology-as-social-essence and technology as 'available' combine to have an impact on the human condition. Heidegger again draws on a

German term, Gestell. 'Gestell' as a noun can mean, 'frame'; for example, the frame of a pair of glasses. Heidegger's intended meaning is normally captured by translating it as 'enframing' (2011, p. 227). This author proposes to illustrate the term further. In colloquial speech in the region of West Yorkshire, England, the verb 'to frame' is used with a metaphorical meaning. To say to someone, 'Frame it!' is to say, 'Sort yourself out' or 'Get your act together'. Thus it is with Heidegger's use of Gestell. Technologies do not take up a passive position within the standing-reserve. They are 'available' in the sense that they frame you. In other words, Heidegger's view of the relationship between technology and the human subject coincides with the words of Arendt cited earlier.

Human subjects are conditioned, 'framed', by their own self-created world.

Another way of illustrating this is to make reference to Lacan's example of the portrait by Holbein titled 'The Ambassadors' (1533). Two resplendent young men are surrounded by a range of scientific instruments and other chattels indicative of a Renaissance underway. However, in the foreground there is an amorphous shape that defies initial recognition. Should the viewer move to view the painting at an oblique angle, the shape is revealed as a human skull. Its anamorphic presence is indicative, we conclude, of the ever-present shadow of mortality. Clearly there is little dispute about which of the two actors, the viewing human subject, and the portrait which presents itself as an object to be viewed, is in the frame. It is the painting that has been framed. Or is it? The artist has shaped the behaviour of the viewing subject who is 'caught, manipulated, captured in the field of vision... we are literally called into the picture' (Lacan, 1977, p. 92). We have been enframed. Similarly, the standing-reserve - the 'available' - of technology frames our being.

\section{Who's in charge? Foucault and the locus of control}

Foucault makes a similar point when he addresses the question of the origins of power. At first sight, the relationship between smartphone and owner is one of tool and user. The locus of control is with the user. The device is his/her inanimate possession to be switched on and off at will. However, Foucault invites us to challenge such basic assumptions by suspending such second order judgements (1972, p.26) and being prepared to ask, quote, 'mad' questions about social and discursive practices (1981, p.48). Power, for Foucault, does not of itself exist. Power, he argues, is a contingent outcome of 'instances of domination, manipulation, edification, control and the like' (Flynn, 1994, p.39). For example, in his study of industrial society, Foucault sees surveillance as the motor of industrial institutions, in the same way that the steam engine was the motor of industrial technologies (1980, p.71).

Foucault's point can be illustrated by making reference to the relationship between the human user and another technological tool, the motor car. Consider the sight of an exotic car driven on a motorway by an equally exotic driver, overtaking you at some speed. There is no doubt as to who is in charge of the vehicle. Or is there? Consider, some while later, seeing the same car on the hard shoulder of the motorway, receiving attention from a breakdown service while the driver looks on. The truth is that the apparent power of the driver is a contingent outcome of a number of other contributing factors. The car needs a mechanic in order to work; it needs fuel in order to move; it 
needs a supply of spare parts. The driver, looking on, is revealed as powerless. Onlookers are obliged to suspend their second-order judgement that drivers are in charge of their cars. As Foucault says:

...power...is exercised through its invisibility; at the same time it imposes on those whom it subjects a principle of compulsory visibility...the examination is, as it were, the ceremony of this objectification. (1977, p.187).

There are few situations more visible, and more powerless, than to be stranded on the hard shoulder of a motorway with a car that refuses to move. The car is no longer a star, and neither is the driver. Similarly, a human deprived of a smartphone can be a sorry spectacle. The device is not so much an instrument of its owner, but a vehicle for the imposition, onto its owner, of expectations and obligations that emanate from the social world: 'For Foucault, power is omnipresent in the social body because it is coterminous with the conditions of social relations in general.' (Gordon, 1980, p.246). You do not operate your smartphone: it operates you. The addictive behaviour that the smartphone can engender is attracting a growing literature: see for example Duke \& Montag (2017) and Fullwood et al (2017). Individuals who are disposed to regard their lives as influenced more by external factors than by their own existential decisions - that is to say, individuals operating under an external locus of control - have been shown to be particularly vulnerable to internet and smartphone dependency (Li, Lepp \& Barkley, 2015; Chak \& Leung, 2004). The smartphone owner is a conditioned being, enframed by the device.

One must therefore ask how the process of 'enframing' happens. What mechanisms are at work? The writings of Louis Althusser on ideology offer a means of explanation.

\title{
Hey you! The interpellated subject
}

\author{
As a first formulation I shall say: all ideology hails or interpellates concrete individuals as \\ concrete subjects...ideology 'acts' or 'functions' in such a way that it 'recruits'... by \\ hailing...'Hey, you there!'
}

The whole mystery of this effect lies in the... ambiguity of the term 'subject'... The individual is interpellated as a (free) subject...in order that he shall freely accept his subjection...

Althusser, 1992, pp 55, 57.

Althusser's application of the term 'ideology' differed from that of his antecedents such as Marx and Gramsci. Althusser saw ideologies everywhere, as invisible, systematic ideas, embedded in common discourse, and implicitly understood. Thus, the greeting, 'How are you?' is not an invitation to articulate a litany of problems. The proper response is 'Very well, thank you'. The term 'interpellate', related to the French term 'appeler' meaning 'to call', can have two meanings. First, it relates to an oral interruption of proceedings in a parliament when explanation is sought. Second, in a philosophical sense, it can mean 'to bring into being'. It is tempting to see Althusser's use as relating to the second meaning, but this author would suggest that the first of the two quotations indicates that Althusser's intention was that 'interpellate', here, relates to the interruption of discourse. 
The effect of interpellation, as Althusser shows in the second quotation, is to reconstitute the human subject. The free-thinking Cartesian subject with the conscious facility to say 'yes' and 'no' is, through the act of interpellation, positioned to offer a response conditioned by the demands of the implicitly-understood ideology that is embedded in the discourse. A passer-by shouts, 'Hey, you there!' and you turn around. An acquaintance asks if you are well, and you reply in the affirmative. The telephone rings, and you answer it. All these are more than invitations. They are interpellations, because they interrupt the prevailing discourse, be it conversation, sightseeing, making a purchase, whatever. The paradox - the 'mystery' as Althusser puts it - is that the freethinking subject becomes subjected; and what is more, he/she accepts his/her subjection without a second thought.

In this way, Heidegger's 'available' technologies do not just facilitate, but demand, attention. To not keep in touch with home, to not respond to messages, to not make use of satellite navigation facilities when they are ever-present on a screen menu, requires a deliberate act of negation which runs contrary to ideological norms. The 'availability' of a technologically-mediated pre-scripted travel route demands that it be used. The discourse of 'home' is the interpelland of the discourse of 'away'. It may be that the maintenance of such contact leads to qualified benefits as well as dis-benefits (Kirillova and Wang, 2016, p.164). It may even lead to a travel experience that is 'more connected, less stressful and even more secure' (Wang, Park and Fesenmaier, 2014, p.24). However, the fact remains that experience of 'away' has become subject - in the sense of subjected - to the exigencies of home.

The experience of 'removal' cannot be liminal, because the pre-condition of separation has not taken place; nor can it be 'escape', because the subject remains diurnally captive to the form and force of the familiar.

\section{Conclusion}

A critique such as this can itself be criticised as an attempt to isolate one facet of life, namely the vacation, and examine the impact of smartphones and social media on that facet of life as if it exists in isolation. The ubiquity of these technologies must lead us to consider that a cyberneticisation of the human condition is taking place. This cybernetic enframing resonates with the conclusions of Molz \& Paris in their study of what they considered to be the evolution of 'backpacking' into technologically-infused 'flashpacking' (2017, p.189-190). A study of the effect of devices on working life led to the identification of a conscious ideology, the 'inviolability of the personal realm', that was under threat through the ubiquity of mobile devices and communications platforms, and the potential they make 'available' for the intrusion of the work sphere into the private sphere (Mullan \& Wajcman, 2017, p.13).

It is important to note that the vacational sphere and the employment sphere are, in this respect, crucially different. The holiday-as-escape discourse is not accompanied by any embedded assumption that home contact is to be avoided. On the contrary: the vacational experience has been shared routinely with home by means of postcards, and photographs shared with family and friends on return. But the locus of control was explicitly with the tourist who, as an 'amateur semiotician' (Urry, 1990, p.139) could be regarded, in Heideggerian terms, as an agent in the enframing of the world (Garlick, 
2002, p.293). The difference, in present times, is that the digital facility for real-time contemporaneous contact has turned the interpellator into the interpellated. Put simply, if mixed-metaphorically, the tables have been turned and the boot is now on the other foot.

The insights of Arendt and Heidegger show how, conceptually, technology is not about technology. Technology, as soon as it becomes 'available', is a resource that 'enframes' human social activity. If we consider the way in which the construction of seaside resorts on the British coast were largely a product and outcome of the railway technologies of the 1840s, or consider how, one hundred years later, internal combustion engine technologies facilitated the spread of holidaymakers from those resorts to parts of the coast and country not served by railways, we can see the point that Heidegger wished to make. That which is different about mobile devices and social media is their ubiquity and ever-presence, and their power to interpellate and subject the individual on a continuous and continual basis.

We have touched on the nature of tourist gratification and the role of the unexpected encounter in delivering satisfaction, as represented in both formal studies and in examples from literature. In this regard it is interesting to reflect on often-quoted words attributed to the American essayist Ralph Waldo Emerson from the mid-19 ${ }^{\text {th }}$ century: 'If a man write a better book, preach a better sermon, or make a better mouse-trap than his neighbour, tho' he build his house in the woods, the world will make a beaten path to his door.'(Emerson, cited in Partington, 1997: 137). These words are usually deployed as an endorsement for free-market capitalism: freedom to make a better mouse-trap.

However, this author would suggest that the key feature is not so much the mouse-trap, but the willingness of the world to undertake the journey into the woods. This is very much a reflection of the Romantic spirit of exploration that was a key cultural feature of the nineteenth century. Would that journey be quite as exciting if the mouse-trap had been researched on the internet first, reviews of the house in the woods were to be had from TripAdvisor, and the journey into the woods was mapped out by a satellite navigation system? The study of Wang et al (2012), cited earlier, shows how smartphones make the navigation of a destination possible, using pre-scripted source material. But this paper has sought to demonstrate shown how serendipitous discovery is a salient gratification of tourist experience. Uncertainty can be fun. Getting lost provides the stuff of stories: see Silas et al (2016, p.45-46).

Indeed, why journey into the woods at all? Why not order online and have the mousetrap delivered with the click of a mouse? No pun intended. Fukuyama, when he wrote The End of History in 1992, could not have anticipated the full facility of the portable communications device. But his drawing of the risk-averse and comfort-seeking 'last man' resonates uncomfortably with the human condition under the hegemony of hyperconnectivity.

\section{References}

Althusser, L. (1992). Ideology and Ideological State Apparatuses. In: A. Easthope \& K. McGowan (Eds) A Critical and Cultural Theory Reader (pp 50-58). Milton Keynes: Open University Paperbacks. 
Arendt, H. (1958). The Human Condition. London: University of Chicago Press.

Braver, L. (2009). Heidegger's Later Writings. London: Continuum.

Chak, K. \& Leung, L. (2004). Shyness and Locus of Control as Predictors of Internet Addiction and Internet Use, Cyberpsychology \& Behavior, 7 (5) 559-570.

Cohen, S. \& Taylor, L. (1992, orig. 1976). Escape Attempts: the theory and practice of resistance to everyday life. London: Routledge.

Dann, G. (1977). Anomie, ego-enhancement and tourism, Annals of Tourism Research, 4 (4), 184-194.

Deloitte (2017) Global Mobile Consumer Survey 2017: the UK Cut. Available from: http://www.deloitte.co.uk/mobileuk/assets/img/download/global-mobile-consumersurvey-2017_uk-cut.pdf Date accessed: November 30 ${ }^{\text {th }}, 2017$.

Dickinson, J., Ghali, K., Cherrett, T., Speed, C., Davies, N. \& Norgate, S. (2014). Tourism and the smartphone app: capabilities, emerging practice and scope in the travel domain, Current Issues in Tourism, 17 (1), 84-101.

Duke, É. \& Montag, C. (2017). Smartphone addiction, daily interruptions and selfreported productivity, Addictive Behaviors Reports, volume 6, pp.90-95.

Flynn, T. (1994) Foucault's Mapping of History. In G. Gutting (Ed.) The Cambridge Companion to Foucault (pp 28-46). Cambridge: Cambridge University Press.

Foucault, M. (1972). The Archaeology of Knowledge. London: Tavistock.

Foucault, M. (1977). Discipline and Punish: The Birth of the Prison. London: Penguin Edition 1991.

Foucault, M. (1980) Questions on Geography. In: C. Gordon (Ed) Michel Foucault: Power/Knowledge (pp 63-77). Hemel Hempstead: Harvester Wheatsheaf.

Foucault, M. (1981). The Order of Discourse. In R. Young (Ed.) Untying the Text: A Post-Structuralist Reader. London: Routledge and Kegan Paul.

Fuchs, C. (2014). Social Media: a critical introduction. London: Sage.

Fukuyama, F. (1992). The End of History and the Last Man. London: Penguin Books.

Fullwood, C., Quinn, S., Kaye, L. \& Redding, C. (2017). My virtual friend: A qualitative analysis of the attitudes and experiences of smartphone users: Implications for smartphone attachment. Computers in Human Behavior, volume 75, pp 347-355.

Garlick, S. (2002). Revealing the unseen: tourism, art and photography. Cultural Studies, 16 (2), 289-305. 
Glaser, E. (2014). Bring back ideology: Fukuyama's 'end of history' 25 years on, The Guardian, $21^{\text {st }}$ March. Available from:

https://www.theguardian.com/books/2014/mar/21/bring-back-ideology-fukuyama-endhistory-25-years-on Date accessed: September $4^{\text {th }} 2017$.

Gordon, C. (1980). Power/Knowledge: Afterword. In: C. Gordon (Ed) Michel Foucault: Power/Knowledge (pp 229-259). Hemel Hempstead: Harvester Wheatsheaf.

Griffin, C., Bengry-Howell, A., Hackley, C., Mistral, W. \& Szmigin, I. (2009). 'Every Time I Do It I Absolutely Annihilate Myself': Loss of (Self-)Consciousness and Loss of Memory in Young People's Drinking Narratives, Sociology, 43 (3), 457-476.

Griffin, C., Bengry-Howell, A., Riley, S., Morey, Y. \& Szmigin, I. (2016). 'We achieve the impossible': Discourses of freedom and escape at music festivals and free parties. Journal of Consumer Culture, Advance online publication: DOI: https://doi.org/10.1177/1469540516684187.

Grit, A. (2014). Messing around with Serendipities. In: S. Veijola, J. Molz, O. Pyyhtinen, E. Höckert \& A. Grit (Eds) Disruptive Tourism and Its Untidy Guests: alternative ontologies for future hospitalities (pp 122-141), Basingstoke: Palgrave Macmillan.

Hamilton-Smith, E. (1987). Four kinds of tourism? Annals of Tourism Research, 14 (3), 332-344.

Hartanto, A. \& Yang, H. (2016). Is the smartphone a smart choice? The effect of smartphone separation on executive functions, Computers in Human Behavior, volume 64, 329-336.

Heidegger, M. (2011). The Question Concerning Technology. In D. Krell (Ed.) Heidegger: Basic Writings (pp 217-238). London: Routledge.

Huxley, L. (2004). Western backpackers and the global experience: an exploration of young people's interaction with local cultures, Tourism, Culture \& Communication, 5 (1), 37-44.

Hyde, K. \& Lawson, R. (2003). The Nature of Independent Travel, Journal of Travel Research, 42 (1), 13-23.

Kirillova, K. \& Wang, D. (2016). Smartphone (dis)connectedness and vacation recovery. Annals of Tourism Research, 61, 157-169.

Krippendorf, J. (1987). The Holiday Makers: understanding the impact of leisure and travel. Oxford: Butterworth-Heinemann.

Lacan, J. (1977). The Four Fundamental Concepts of Psycho-Analysis. London: Karnac.

Lash, S. \& Urry, J. (1994). Economies of Signs \& Space. London: Sage. 
Li, J., Lepp, A. \& Barkley, J. (2015). Locus of control and cell phone use: Implications for sleep quality, academic performance, and subjective well-being, Computers in Human Behavior, volume 52, 450-457.

MacCannell, D. (2001). Tourist Agency, Tourist Studies, 1 (1), 23-37.

MacKay, K. \& Vogt, C. (2012). Information Technology in Everyday and Vacation Contexts. Annals of Tourism Research, 39 (3), 1380-1401.

Mansion, M. (1967). Harrap's Shorter French and English Dictionary. London: Harrap.

Miller, V. (2012). A Crisis of Presence: On-line Culture and Being in the World. Space and Polity, 16 (3), 265-285.

Molz, J. \& Paris, C. (2015). The Social Affordances of Flashpacking: Exploring the Mobility Nexus of Travel and Communication. Mobilities, 10 (2), 173-192.

Mullan, K. \& Wajcman, J. (2017). Have mobile devices changed working patterns in the $21^{\text {st }}$ century? A time-diary analysis of work extension in the UK. Work, Employment and Society, Advance online publication: DOI: 10.1177/0950017017730529.

ONS (Office for National Statistics) (2017). Contracts that do not guarantee a minimum number of hours: September 2017. London: ONS. Available from:

https://www.ons.gov.uk/employmentandlabourmarket/peopleinwork/earningsandworkin ghours/articles/contractsthatdonotguaranteeaminimumnumberofhours/september2017 Date accessed: March $10^{\text {th }}, 2018$.

Park, N., Kim, Y-C., Shon, H. \& Shim, H. (2013): Factors influencing smartphone use and dependency in South Korea. Computers in Human Behavior, 29 (4), 1763-1770.

Partington, A. (1997). The Concise Oxford Dictionary of Quotations. Oxford: Oxford University Press.

Pielichaty, H. (2015) Festival space: gender, liminality and the carnivalesque. International Journal of Event and Festival Management, 6 (3), 235-250.

Pritchard, A. \& Morgan, N. (2010). 'Wild On' the Beach: Discourses of Desire, Sexuality and Liminality. In E. Waterton \& S. Watson (Eds) Culture, Heritage and Representation: perspectives on visuality and the past (pp 127-143). Farnham: Ashgate.

Ringer, G. (1998). Destinations: Cultural Landscapes of Tourism. London: Routledge.

Ryan, C. (1997). The Tourist Experience: a new introduction. London: Cassell.

Sandywell, B. (2011). Dictionary of Visual Discourse: A Dialectical Lexicon of Terms. Farnham: Ashgate.

Shields, R. (1990). The 'system of pleasure': liminality and the carnivalesque at Brighton. Theory, Culture \& Society, 7 (1), 39-72. 
Silas, E., Løvlie, A. \& Ling, R. (2016). The smartphone's role in contemporary backpacking experience. Networking Knowledge, 9 (6) 40-55. Available from: https://ojs.meccsa.org.uk/index.php/netknow/article/view/491/314 Date accessed: 1611-17.

Statista (2017) Social Media and User-Generated Content: Facebook active users. Available from: https://www.statista.com/statistics/264810/number-of-monthly-activefacebook-users-worldwide/ Date accessed: 30 ${ }^{\text {th }}$ November 2017.

Statista (2017a) Social Media and User-Generated Content: Twitter active users. https://www.statista.com/statistics/282087/number-of-monthly-active-twitter-users/ Date accessed: $30^{\text {th }}$ November 2017.

Stendhal (1962, orig.1838). Memoirs of a Tourist. Translator: Allan Seager. USA: Northwestern University Press.

Turner, V. (1969). The Ritual Process: structure and anti-structure. London: Routledge \& Kegan Paul.

Urry, J. (1990). The Tourist Gaze: leisure and travel in contemporary societies. London: Sage.

Urry, J. (2000). Sociology Beyond Societies: mobilities for the twenty-first century. London: Routledge.

Urry, J. (2007). Mobilities. Cambridge: Polity Press.

Van Gennep, A. (1960, orig.1909). The Rites of Passage. Chicago: Chicago University Press.

Voase, R. (2002). Tourism in Western Europe. Wallingford: CABI.

Wang, D., Park, S. \& Fesenmaier, D. (2012). The role of smartphones in mediating the touristic experience. Journal of Travel Research, 51 (4), 371-387.

Wang, D., Xiang, Z. \& Fesenmaier, D. (2014). Adapting to the mobile world: A model of smartphone use. Annals of Tourism Research, 48 (1), 11-26,

Wang, D., Xiang, Z. \& Fesenmaier, D. (2016). Smartphone use in Everyday Life and Travel. Journal of Travel Research, 55 (1), 52-63.

Wang. L. \& Alasuutari, P. (2017). Co-construction of the tourist experience in social networking sites: Two forms of authenticity intertwined. Tourist Studies, 17 (4), 388405.

White, N. \& White, P. (2007). Home and away: tourists in a connected world. Annals of Tourism Research, 34 (1), 88-194. 
Wolniewicz, C., Tiamiyu, M., Weeks, J. \& Elhai, J. (2017). Problematic smartphone use and relations with negative affect, fear of missing out, and fear of negative and positive evaluation, Psychiatry Research, Advance online publication:

http://dx.doi.org/10.1016/j.psychres.2017.09.058

Wordsworth, W. (1969). Wordsworth: Poetry \& Prose. Selected by W. M. Merchant. London: Rupert Hart-Davis. 